Univerzitet u Beogradu
Poljoprivredni fakultet
Institut za poljoprivrednu tehniku
Naučni časopis
POLJOPRIVREDNA TEHNIKA
Godina XLV
Broj 2, 2020.
Strane: $37-44$
Faculty of Agriculture
$\begin{array}{r}\text { Iniversity of Belgrade } \\ \text { Institute of Agricultural Engineering } \\ \text { Scientific Journal }\end{array}$
AGRICULTURAL ENGINEERING
Year XLV
No. 2, 2020.
pp: $37-44$

UDK: 338.43.1.

\title{
APPROVAL OF FINANCIAL ANALYSIS IN THE MANAGEMENT OF AGRICULTURAL COMPANY
}

\author{
Stojanka Radović* ${ }^{1}$ \\ ${ }^{I}$ PhD student, Faculty of Economics, University of Banja Luka, \\ Majke Jugovića 4, 78000 Banja Luka, Bosnia and Herzegovina
}

\begin{abstract}
An agricultural company is a living organism that tends to evolve. In order to achieve this, it is necessary to implement adequate planning, establish controls and analytical procedures that are used in all aspects of the business. For decades, agricultural companies have been dominated by accounting analysis, which included, above all, adequate monitoring of the process through analysis in the financial statements, and in particular the analysis of data relevant to the operation of any enterprise. The application of modern accounting analysis should provide the management of the company with a wide range of opportunities regarding the continuous growth and development of the company in accordance with the set goals. However, this is not enough. Modern financial management does not rule out an accounting approach, but it does introduce a complete observation of the financial situation in the company, fair valuation of the assets of the company, realistic financial reporting, through the implementation of a realistic financial report obtained by the top management by the sector managers and departments in the company.
\end{abstract}

Key words: short food supply chain; distribution; sustainability; information

\section{INTRODUCTION}

Until 20 years ago, financial analysis was exclusively related to accounting analysis as a term often used in the professional circles, denoting an essential analysis of the company's business [1], [2], [3], [4], [5].

*Corresponding author. Email: radovic.stojanka77@gmail.com 
The application of modern accounting analysis has, over the decades, yielded certain results that were not sufficiently sufficient to effectively manage companies [6], [7], [8], [9], [10], especially when they were largely traded and when realistic valuation of the company was required.

Basically, the financial statements change and are consolidated.

This was particularly favored by the increasing and significant harmonization of international accounting standards. They recognize the five basic financial statements: balance sheet, income statement, cash flow statement, statement of changes in equity and notes to the financial statements.

Based on this structure, contemporary analysis identifies the aforementioned financial statements as a primary subject of interest and can be defined as a set of measures, actions and activities that aim to put the numerical information in the financial statements in an appropriate relationship with the purpose of providing new numerical (real) value. Some outsiders consider such an approach to be a specific indicator of the quality (adequacy) of an enterprise.

This study presents not only an approach that respects the concept of accounting analysis but also an approach that analysis can take to the overall business of a company. Essential attention is focused on: analysis of financial statements, its significance, comparative and summary financial statements, as well as comparative and process analysis of financial statements.

All applicable procedures should be used to improve the business [11], [12], [13], [14], [15], primarily by the continuous and systematic monitoring of the overall process that accompanies the financial reporting process.

\section{MATERIALS AND METHODS}

For the preparation of this paper, the author has placed the focus of research on financial analysis as a basis for reporting to top management of an agricultural enterprise. The research involved, first and foremost, the theoretical gathering of valid information on the basis of which it is possible to make a theoretical model of the practical application of a given research goal that the author has set for himself. This is done in the view given in Figure 1-2.

In the second part of the research, the author gave an overview of the top management's real reporting to the state authorities in the form of a specific company balance sheet (Table 1) and presented a table 2 of the balance sheet changes over the course of several years with a presentation of the size changes.

The aim of applying the presented methods in this paper was to give a model that would take into account possible reporting, that is, to put top management reporting in the focus of reporting as possible and realistically acceptable in the real economy of an agricultural enterprise. 


\section{RESULTS}

In order to ensure adequate conditions for the development of a company, it must have good and modern organized management in all its parts of the company.

In this context, the importance of implementing a business analysis of a company is dominant. It can provide information that is relevant to modern enterprise management, which essentially means good management of the enterprise resources. In doing so, the overall analysis seeks to fully cover all relevant data and information, be it monetary or material information that is generated within the enterprise and that is collected within the company. The analysis of financial statements is primarily focused on the value or financial information presented in the financial statements that are submitted to top management for decision making. The analysis of financial statements focuses primarily on quantitative financial information and is therefore often referred to as quantitative financial analysis.

The three most important areas are generally thought to dominate the origins and development of financial analysis. The most important areas in almost every company are: financial management, management accounting and financial accounting. The analysis of the financial statements strives for and directs its outlook on the future, highlighting those aspects of business that are relevant to market survival, and above all are the safety and efficiency of the business, which is of utmost importance in the functioning of an agricultural enterprise. Viewed only from a financial standpoint, business analysis for the needs of the manager must include an analysis of financial results, financial conditions, financial structure and changes in financial structure.

Analysis of financial statements can be defined as the process of applying various analytical tools, methods and techniques by which the data from financial statements is transformed into usable information, relevant to the modern management of the company.

Common analytical tools and methods generally used in standard financial statement analysis are:

- comparative financial statements,

- considering the tendency of change through a number of relevant indices;

- summary financial statements;

- indicator analysis;

- special non-standard analysis.

The importance of financial statement analysis is seen in the context of modern business management and agricultural enterprise development. The analysis precedes the management process. Any quality and sound financial plan must take into account the desirable characteristics of the company on the other hand and its potential weaknesses.

The primary task of analyzing financial statements is actually to identify good performing companies in order to reap the full benefits of the company, but also to appreciate the weaknesses of the company so that corrective action can be taken. The analysis of the financial statements therefore provides information as a basic input from which to reflect and judge business activities for the purpose of making appropriate decisions. 
The author points out that apart from the modern management of the company, other participants also appear, who want to obtain relevant information for decision making in the work of their legal entities. The author presented the possible scheme of participants in the form of picture number 1 .

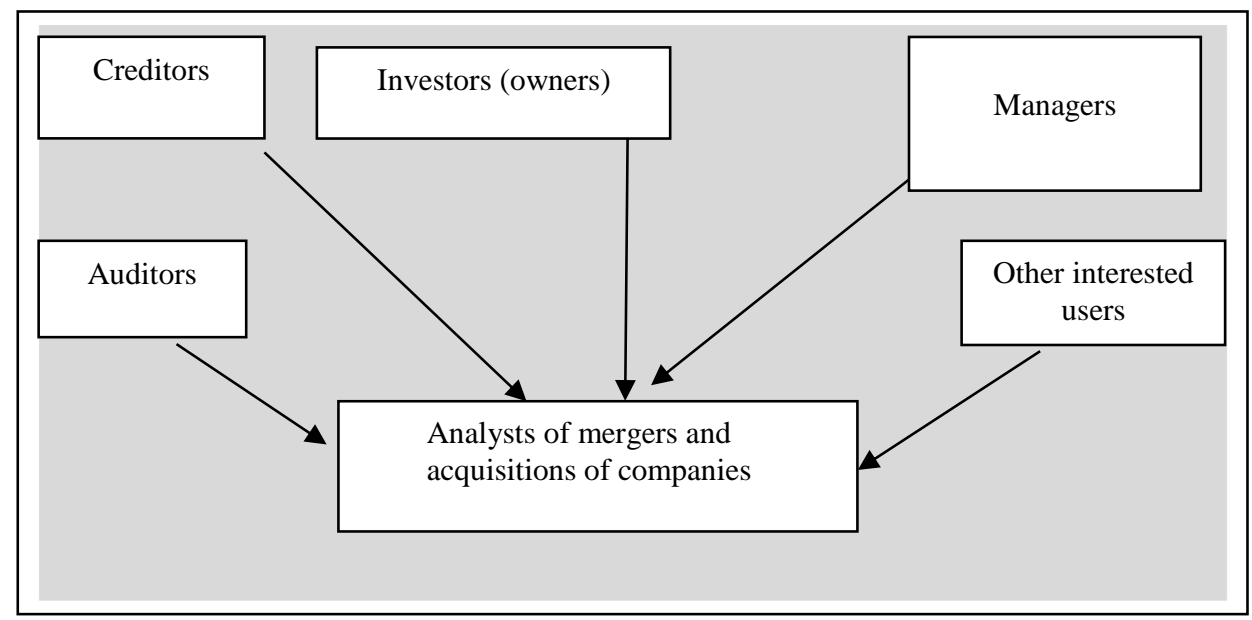

Figure 1. Outline of possible subjects interested in obtaining essential information necessary for modern decision-making and management.

Case study presentation of a practical balance sheet of an enterprise that is essential for making valid management decisions.

The author gives an overview of the actual balance of the company, to illustrate the importance of data for financial and any other analysis in the company. For a better understanding of the foregoing, the author provided an overview of the actually completed balance sheet of the companies whose generals are not listed, as well as the business year for which the views were given.

The presentation itself is presented in Table No.2, as well as the Financial Statement Analysis, which enables comparisons of data over a longer period to identify trends and dynamics of changes in certain balance sheet items Table No. 1.

Table 1. Balance sheet changes over several years

Tendencies of changes in the income statement.

\begin{tabular}{|l|c|c|c|c|c|}
\hline \multicolumn{7}{|c|}{ Status at 31. 12. } \\
\hline Business year & 1 & 2 & 3 & 4 & 5 \\
\hline NETO SALES & 100 & 103 & 145 & 173 & 222 \\
\hline GROSS PROFIT & 100 & 102 & 104 & 105 & 142 \\
\hline NETO PROFIT & 100 & 101 & 105 & 117 & 166 \\
\hline
\end{tabular}


Table 2. View of the actual balance sheet of a real enterprise with reported sizes that truly reflect the business of an unnamed company

\begin{tabular}{|c|c|c|c|c|}
\hline \multicolumn{5}{|c|}{ Comparative Balance Sheet } \\
\hline & \multicolumn{2}{|c|}{ Status at 31.12.} & \multirow{2}{*}{$\begin{array}{l}\text { Ammount of } \\
\text { increase } \\
\text { (decrease) }\end{array}$} & \multirow{2}{*}{$\begin{array}{l}\text { Percentage } \\
\text { of increase } \\
\text { (decrease) }\end{array}$} \\
\hline & \begin{tabular}{|l} 
previous \\
business year
\end{tabular} & $\begin{array}{l}\text { current } \\
\text { business } \\
\text { year }\end{array}$ & & \\
\hline \multicolumn{5}{|l|}{ ASSETS (in 000 RSD) } \\
\hline \multicolumn{5}{|l|}{ PROPERTY, PLANTS AND EQUIPMENT: } \\
\hline - land & 4.300 & 4.520 & 220 & 5,1 \\
\hline -facilities & 72.540 & 72.540 & - & - \\
\hline Less: value adjustment & $(29.196)$ & $(30.696)$ & $1.500^{*}$ & 5,1 \\
\hline - equipment & 16.717 & 18.907 & 2.190 & 13,1 \\
\hline Less: value adjustment & $(7.840)$ & $(7.980)$ & $140^{*}$ & 1.8 \\
\hline TOTAL PROPERTY, PLANTS AND EQUIPMENT & 56.521 & 57.291 & 770 & 1,4 \\
\hline \multicolumn{5}{|l|}{ LONG-TERM INVESTMENTS: } \\
\hline - Investments in ordinary shares & $\underline{6.000}$ & $\underline{6.000}$ & - & - \\
\hline \multicolumn{5}{|l|}{ CURRENT ASSETS } \\
\hline - cash & 6.574 & 5.368 & $(1.206)$ & $(18,3)$ \\
\hline - securities & 1.570 & 3.090 & 1.520 & 96,8 \\
\hline - claims (net) & 32.936 & 35.382 & 2.446 & 7,4 \\
\hline - supplies of goods & 50.434 & 62.582 & 12.148 & 24,1 \\
\hline - subscription costs & 2.590 & 2.870 & $\underline{280}$ & $\underline{10.8}$ \\
\hline TOTAL CURRENT ASSETS & $\overline{94.104}$ & $\overline{109.292}$ & $\overline{15.188}$ & $\overline{16,1}$ \\
\hline TOTAL ASSETS & 156.625 & 172.583 & 15.598 & 10,2 \\
\hline \multicolumn{5}{|l|}{ LIABILITIES (in 000 RSD) } \\
\hline \multicolumn{5}{|l|}{ SHAREHOLDERS 'EQUITY } \\
\hline \multicolumn{5}{|l|}{ - preferred shares } \\
\hline $5 \%$ (nom. value 10$)$ & 500 & 500 & & \\
\hline - ordinary shares (nom. value 1) & 9.500 & 10.000 & 500 & 5,3 \\
\hline - capital profit & 30.053 & 35.843 & 5.790 & 19,3 \\
\hline - retained earnings & 47.657 & 57.207 & 9.550 & 20.0 \\
\hline TOTAL SHAREHOLDERS 'EQUITY & 87.710 & 103.550 & 15.840 & 18,1 \\
\hline \multicolumn{5}{|l|}{ LONG-TERM LIABILITIES: } \\
\hline - mortgage bonds $8 \%$ & 28.000 & 25.000 & $(3.000)$ & $(10,7)$ \\
\hline - unsecured bonds $10 \%$ & & 5.000 & 5.000 & $\alpha$ \\
\hline TOTAL LONG-TERM LIABILITIES & 28.000 & 30.000 & 2.000 & 7.1 \\
\hline \multicolumn{5}{|l|}{ CURRENT LIBILITIES: } \\
\hline - payment invoices & 33.353 & 29.235 & $(4.118)$ & $(12,3)$ \\
\hline - taxes & 2.425 & 3.040 & 615 & 25,4 \\
\hline - other current liabilities & 2.137 & 3.758 & 1.621 & 75,9 \\
\hline - current portion of long-term liabilities & 3.000 & 3.000 & & \\
\hline TOTAL CURRENT LIBILITIES & 40.915 & 39.033 & $(1.882)$ & $(4,6)$ \\
\hline TOTAL LIABILITIES & 68.915 & 69.033 & 118 & 0.2 \\
\hline TOTAL PASSIVE BALANCE & 156.625 & 172.583 & 15.958 & 10,2 \\
\hline
\end{tabular}




\section{DISCUSSION}

The author emphasizes the importance that the management of an agricultural enterprise should take into account the basic characteristics of information that can be obtained by analyzing all parts of the company when preparing financial statements.

Obsolete or inaccurate information is useless, as is information that is true, but whose method of obtaining it is too complicated and expensive and therefore it is not desirable for the company to access it in such an economically unacceptable way. Therefore, management needs to find the optimal balance between all the attributes that characterize the information and the associated costs.

Only information created under these conditions, provided in a timely manner to top management, will have great practical value for making management's valid business decisions in managing an agricultural enterprise.

Part of the basic methods used in the analysis of financial statements is presented by the authors in this study, with the aim, among other things, to present real-world reporting on the example of a company in the balance sheets.

\section{CONCLUSIONS}

Financial reporting that involves the realistic preparation of financial statements is becoming increasingly important in the real operations of various companies. Financial reporting is used as a basis for conducting comparative analyzes, while summary financial statements are used to analyze the process.

This is especially true in manufacturing companies such as agricultural companies. The application of such financial reporting through comparative analysis can best be explained as a method of comparing an entity in two different periods.

Comparison requires certain prerequisites:

1. It is necessary to keep unique records in companies;

2. It is necessary to provide an equal time interval for the analysis;

3. The related data groups must be compared;

4. When comparing between companies, the size of the company, etc. must be taken into account.

The process analysis method is used to review the structure of a specific and complex subject of analysis, especially in the agricultural enterprises, especially in the summary financial statements, which the study author illustrated and illustrated in Table 1 and Table 2.

The general conclusion is that the use of this approach, as outlined in the study, is justified and necessary, especially in the production companies of such agricultural enterprises, as they are most likely to see the results of operations submitted in the form of financial reports to top management. 


\title{
REFERENCES
}

[1] Williams C. 2010. Principi menadžmenta. Data Status. Beograd.

[2] Popović S. 2014. Socio-ekonomski faktori ograničenja razvoja agrara. Feljton, Serbia.

[3] Popović S, Tošković J \& Grublješić Ž.2014. Environmental-Economic Model of Developing Composters in Parks, Protected Areas and City Limits in the Republic of Serbia. ProEnvironment, 7: 213-217.

[4] Popović S., Novaković S., Đuranović D, Mijić R., Grublješić Ž., Aničić J.. \& Majstorović A. 2017a. Application of international accounting standard-16 in a public company with predominantly agricultural activities. Economic Research. 30:1, 1850-1864.

[5] Popović S, Jovin S, Đuranović D, Popović V, Filipović V, Munitlak-Ivanović O, Grublješić Ž, Mijić R.2017b. The Importance of Planting Pot Marigolds (Calendula officinalis L.) in degraded public spaces from the agroecological and economic perspective. Contemporary Agriculture. 66 (1-2) 27-31.

[6] Rønsted N., Savolainen V., Mølgaard P \& Jäger A. 2008. Phylogenetic selection of Narcissusspecies for drug discovery. Biochemical Systematics and Ecology. 417-422.

[7] Ege, M. S. 2015. Does internal audit function quality deter management misconduct ?. The Accounting Review. 90(2): 495-527.

[8] Flecher, K. 2003. Upravljanje marketingom i IT. Klio. Beograd, pp. 490.

[9] Greuning, H. 2006. Međunarodni standardi finansijskog izveštavanja. Mate. Zagreb.

[10] Ivaniš, M. and Popović, S.2013. Altmanov Z-Score model analize. Ekonomija-teorija $i$ praksa. 2: 47-62.

[11] Ljutić, B. 2014. Finansijsko računovodstvo: alati za donošenje poslovnih odluka. Univerzitet privredna akademija. Feljton. Novi Sad. Srbija, str. 1-434..

[12] Majstorović, A., Popović, S., Volf, D. 2015. Teorija i politika bilansa. Alfa-graf. Novi Sad.

[13] Popović, S., Đuranović, D., Eremić-Đođić, J., Jovin, S., Popović, V., Filipović, V. 2017. Audit as factor of improvement of management in agricultural company. Poljoprivredna tehnika, 4: $9-14$.

[14] Selarka, E. 2005. Ownership concentration and firm value. Emerging Markets Finance and Trade, 41(6): 83-108.

[15] Soltani, B. 2009. Revizija, Međunarodni pristup, Mate, Zagreb.

\section{UVAŽAVANJE FINANSIJSKE ANALIZE U UPRAVLJANJU POLJOPRIVREDNIM PREDUZEĆEM}

\author{
Stojanka Radović ${ }^{1}$ \\ ${ }^{1}$ Student Doktorskih studija, Ekonomski Fakultet, Univerzitet u Banja Luci, \\ Majke Jugovića 4, 78000 Banja Luka, Bosna i Hercegovina
}

Sažetak: Poljoprivredna kompanija je živi organizam koja teži da se razvija. Da bi se to ostvarilo potrebno je implementirati adekvatno planiranje, uspostaviti kontrole i analitičke postupake koji se koriste u svim aspektima poslovanja.

U poljoprivrednim kompanijama decenijama unazad je dominirala računovodstvena analiza, koja je uključivala pre svega adekvatno nadgledanje procesa putem analize u finansijskim izveštajima a naročito analizu podataka koji su bitni za rad bilo kog preduzeća. 
Primena savremenih računovodstvenih analiza treba da pruži rukovodstvu preduzeća širok spektar mogućnosti u pogledu neprekidnog rasta i razvoja kompanije u skladu sa unapred postavljenim ciljevima. Međutim to nije dovoljno, Savremeno finansijsko upravljanje ne isključuje računovodstveni pristup, ali uvodi celokupno posmatranje finansijske situacije u preduzeću, fer vrednovanje imovine preduzeća, realno finansijsko izvještavanje, putem primene realnog finansijskog izveštaja kojeg dobija sam top menadžment od strane rukovodioca sektora i odeljenja u preduzeću.

Ključne reči: upravljanje, finansijska analiza, poljoprivredno preduzeće.

Prijavljen:

Submitted:

24.01.2020

Ispravljen:

Revised:

04.05.2020

Prihvaćen:

Accepted:

22.05.2020 